\title{
Typology of family livestock production systems in the Pampa biome using the MESMIS method
}

\section{Tipologia dos sistemas de produção da pecuária familiar no bioma pampa utilizando o método MESMIS}

\author{
Carolina da Silveira Nicoloso ${ }^{1 *}$; Vicente Celestino Pires Silveira ${ }^{2}$; Roblein Cristal \\ Coelho Filho ${ }^{3}$; Fernando Luiz Ferreira de Quadros $^{2}$
}

\begin{abstract}
Livestock farming plays a significant role in Rio Grande do Sul state. The current global dynamics of grain appreciation have triggered the advance of agricultural production, especially soybean, over the gaucho Pampa biome. These changes determine the path of production system sustainability; however, it remains unclear how sustainable these production systems are. A typology of 90 family livestock production systems in the Pampa biome was performed as a function of sustainability using the MESMIS method and cluster analysis. The production systems were grouped into three different groups: SPPF, least sustainable, with a higher percentage of crops in the systems, more soybean crops, lower share of income from livestock production, and less native field area. SPPF more sustainable, presented greater sustainability, with smaller crop areas in relation to the total area, more native field in the systems, a more standardized herd, greater crop diversification, and a higher level of formal education and producer participation. SPPF intermediary presented higher productivity then the least sustainable SPPF, self-sufficiency equal to that of the other groups, and similar results to SPPF least sustainable for the other attributes $(\mathrm{p}<0.05)$.
\end{abstract}

Key words: Sustainability. Small livestock farmers. Soybeans. Typology.

\section{Resumo}

A pecuária desempenha um papel significativo no estado do Rio Grande do Sul. A atual dinâmica de valorização dos grãos, ocorrida em nível global, desencadeou o avanço da produção agrícola, especialmente da soja, sobre o bioma gaúcho do Pampa. Essas mudanças determinam o caminho de sustentabilidade dos sistemas de produção; e quão sustentáveis são esses sistemas de produção? Uma tipologia de 90 sistemas de produção da pecuária familiar no bioma Pampa foi realizada em função da sustentabilidade, utilizando o método MESMIS e análise de agrupamento. Os sistemas de produção foram agrupados em três grupos distintos: SPPF menos sustentável, apresentou maior percentual de lavouras nos sistemas, mais lavouras de soja, menor participação da produção pecuária, menor área de campo nativa. O SPPF mais sustentável, teve menores áreas de lavouras em relação à área total, mais campo nativo nos sistemas, rebanho mais padronizado, maior diversificação de culturas e maior nível de educação formal e participação dos produtores. O SPPF intermediário apresentou maior produtividade que o SPPF menos sustentável, autossuficiência igual aos demais grupos e resultados semelhantes ao SPPF menos sustentável para os demais atributos $(p<0,05)$.

Palavras-chave: Sustentabilidade. Pecuária familiar. Soja. Tipologia.

1 Dr ${ }^{\mathrm{a}}$ em Extensão Rural, Universidade Federal de Santa Maria, UFSM, Santa Maria, RS, Brasil. E-mail: carolinanicoloso@ hotmail.com

2 Profs. Drs., UFSM, Santa Maria, RS, Brasil. E-mail: vcpsilveira@gmail.com; flfquadros@yahoo.com.br

3 M.e, Eng ${ }^{\circ}$ Agr ${ }^{\circ}$, Empresa Paranaense de Assistência Técnica Extensão Rural, EMATER, Santa Maria, RS, Brasil. E-mail: rfilho@ emater.tche.br

* Author for correspondence 


\section{Introduction}

Cattle raising is a traditional activity in Rio Grande do Sul (RS), which since the formation of the state, has influenced its socio-cultural and economic formation. The 'Sesmarias' donation system was the basis of farm implantation in RS state, where cattle breeding expanded by large areas rich in natural pastures, making livestock the main economic activity of the state. According to Rodrigues (2006), farms are one of the most important socioeconomic segments in the history of Rio Grande do Sul, based on extensive livestock farming on large estates, with many animals and abundant natural pastures. The arrival of settlers sent by the Portuguese crown in the 18th century resulted in a new organization of work and a new configuration of land patrimony, which can explain the historical presence of small cattle farmers in Rio Grande do Sul (WAQUILL et al., 2016).

Hence, the social category called family livestock in RS has been regulated by law since 2011, whereby the condition of family farmers is defined by Decree No. 48,316, August 31, 2011 (RIO GRANDE DO SUL, 2011). Family livestock production uses predominantly family labor, with a minimum income of $70 \%$ obtained from activities performed in a rural establishment of a maximum 300 hectares, which they own.

Family livestock plays a significant role in RS due to its social characteristics and from the point of view of management systems, whereby its practices favor the conservationist and more extensive production, mainly in the Pampa biome. This biome confers features and peculiarities to the region, which directly influence the area's suitability for livestock activity. The grassy vegetation, with open and wide plains of grass fields, includes some areas with more dense vegetation, pine forests in the vicinity of the rivers and waterways, and the presence of plains (CHOMENKO, 2006). It comprises most of the central-south region of RS state, including Plateau da Campaign, Plateau Sul-Rio-Grandense, Central Depression, and Coastal Plain.
The Pampa biome has a natural and cultural heritage, and extensive cattle ranching over area, which is the main economic activity, has allowed the conservation of fields and the development of a unique mestizo culture of a transnational character represented by the Gaucho (BRASIL, 2014).

Despite the provision for cattle breeding in the Pampa biome, the current worldwide dynamics of grain valorization have triggered the advance of agricultural production, especially soybeans, over the Pampa gaucho. The expansion of soybean growing areas in the Pampa biome since 2000 (PIZZATO, 2013) in areas traditionally used for extensive cattle raising and rice production is transforming this region. Pizzato (2013) observed an increase in the area destined for soybean cultivation and a decrease in the area for livestock and rice cultivation in the Pampas. However, the author noted that the production of beef cattle did not decrease. This shows that the profile of the livestock industry in Rio Grande do Sul has changed and is producing more in over a smaller area (PIZZATO, 2013). Silveira et al. (2017) demonstrated changes in land use in the region, which were influenced by the appreciation of grain in the domestic and external market; soybean became the largest commercial crop of the Pampa in 2003, increasing by $1,192,115$ ha between 2000 and 2015. Maintenance of bovine herd size in the region is linked to the use of cultivated pastures in the winter for animal production, where soybean is cultivated in the summer.

Although profitability is the greatest call for soybean input in productive systems, the proper management of native fields competes in profitability with agriculture. Historically, livestock farming in the Pampa biome has been linked to the social and cultural development of the region.

In this sense, family farming contributes greatly to the conservation of the Pampa biome due to production systems that favor more extensive and conservationist production. Despite this, the low utilization of technologies by this type of cattle rancher (family farmer) results in low productivity, which is the key to soybean expansion in these areas. 
These dynamics result in changes in the productive systems, which affect the cattle ranchers, who change their way of managing this activity. The family farmer, defined by the typology of Ribeiro (2009), is thus inserted into new types of production systems resulting from changes that arise due to the dynamics of soybean in the Pampa biome, and these changes determine the path of sustainability of these production systems. However, it remains unclear how sustainable these production systems are.

There are several definitions of sustainability in agriculture, which all emphasize the need to address the ecological, economic, and sociological consequences of development choices for present and future generations (GIBON et al., 1999; BELZLEPKINA et al., 2011).

The sustainability of agricultural systems depends on many often inter-related factors, which differ between systems and change over time. Therefore, recent reports evaluating the sustainability of agricultural systems advocate the adoption of integrated, flexible, participatory, and multi-scale approaches to address complex issues involving various disciplines and stakeholders (BARBIER; LÓPEZ-RIDAURA, 2010).

Among the methods developed to evaluate sustainability, the Framework for Evaluation of Natural Resource Management Systems Incorporating Sustainability Indicators (MESMIS) follows a holistic approach, which can be applied on different scales, including the farm, and ensures universal applicability for the management of natural resources (level of attributes). This structure is organized around sustainability attributes (productivity, stability, adaptability, equity, and self-sufficiency), although these are related to the three pillars of sustainability (economic, social, and environmental) (LÓPEZ-RIDAURA et al., 2002). MESMIS is a bottom-up, participatory, and interdisciplinary process (BINDER et al., 2010), in which sustainability is not measured by itself, but is expressed in comparative terms between two or more systems or between different stages of the same system. It has been widely used to assess the sustainability of production systems of small farmers in different countries and agroecological regions (SPEELMAN et al., 2007).

The objective of this study was to evaluate the sustainability of family farmer production systems (SPPF) after the introduction of soybeans located in areas of the Pampa biome, through production system typologies.

\section{Material and Methods}

The MESMIS framework allows sustainability indicators to be derived, measured, and monitored as part of a systemic, participatory, interdisciplinary, and flexible evaluation process (LÓPEZ-RIDAURA et al., 2002). The structure is based on seven defined sustainability attributes (productivity, stability, reliability, resilience, adaptability, equity, and self-sufficiency), although indicators can also be classified into three pillars of sustainability (environmental, social, and economic). The systemic attributes defined are:

(A) Productivity (ability to provide the required level of goods and services).

(B) Stability (ability to maintain a constant level of productivity under normal conditions).

(C) Reliability (maintaining productivity near equilibrium levels under normal conditions of environmental disturbance).

(D) Resilience (return to equilibrium or levels of productivity similar to the initial level after serious disturbance).

(E) Adaptability or flexibility (ability to find new levels of balance or to continue to offer benefits for long-term environmental changes).

(F) Fairness (the ability of the system to distribute intra- and intergenerational benefits and costs in a fairly manner).

(G) Self-sufficiency (ability of the system to regulate and control external interactions). 
The attribute stability, reliability, and resilience can be grouped (hereafter referred to as "stability") to express the system's ability to cope with change (LÓPEZ-RIDAURA et al., 2002). Together with adaptability, these attributes help to dynamically analyze the sustainability of agricultural systems, allowing consideration of the physical and socioeconomic context in which production systems operate.

This research was developed with the support of EMATER/RS (Technical Assistance and Rural Extension Company), regional of Santa Maria. The regional is composed of 35 municipalities of which 20 participated in the study through the collaboration of their municipal livestock technicians (Figure 1). Thus, there was a total of 90 production systems in 20 municipalities (Cacequi, Cachoeira do Sul, Dilermando de Aguiar, Formigueiro, Jaguari, Jari, Nova Esperança do Sul, Paraiso do Sul Pinhal Grande, Quevedos, Restinga Seca, Santa Maria, Santiago, São Francisco de Assis, São Martinho da Serra, São Pedro do Sul, São Sepé, São Vicente do Sul, Unistalda, and Vila Nova do Sul).

Figure 1. Map of RS state including the 20 municipalities where the production systems studied are located.

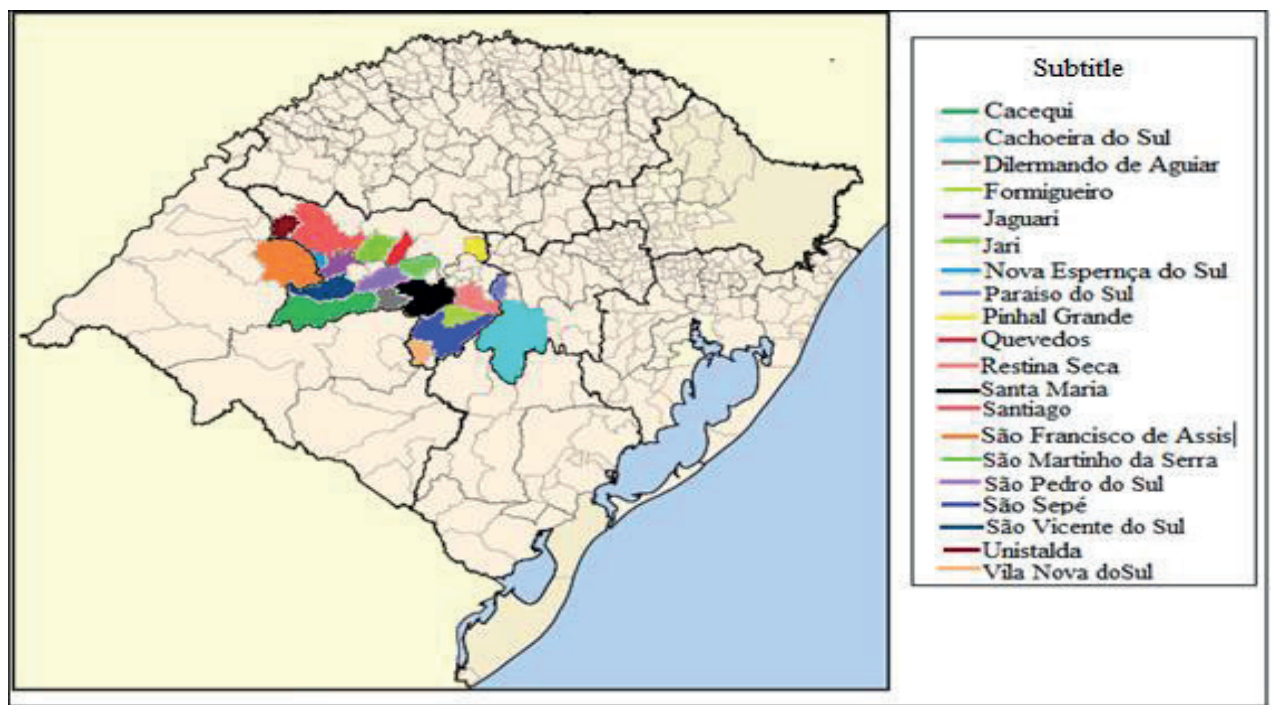

Source: Speelman et al. (2007).

The operational structure of the MESMIS consists of six stages:

Stage 1 - definition and description of the system or systems to be evaluated.

Stage 2 - identification of critical points of the system: positive or negative aspects that provide strength or vulnerability, i.e., socioeconomic factors, techniques, or processes that individually or in combination can have a crucial effect on the attributes of the systems described.

Stage 3 - selection of diagnostic criteria and indicators: the purpose of this process is to provide the necessary link between attributes and critical points on one side, and critical points and indicators, on the other. The difference between diagnostic criteria and indicators is that the former describes the attributes of sustainability and the latter describes a specific process within the system.

The operationalization of the first three stages of the MESMIS method was developed from October 2013 to March 2014 and then, from April to September 2015. Thus, the object of study (Stage 1) was defined at a meeting of researchers and extensionists, belonging to the Federal University of Santa Maria (UFSM) and EMATER Santa Maria. 
In the second stage (Stage 2), a meeting was held between researchers and the municipal field technicians of EMATER Santa Maria, on October 16th, 2013. The methodology was presented, and the weaknesses and strengths of the production systems under study, as well as their opportunities and weaknesses, were evaluated through a strengths, weaknesses, opportunities, and threats (SWOT) analysis (Table 1).

Table 1. SWOT analysis for the family livestock production systems in the Pampa biome.

\begin{tabular}{ll}
\hline Strengths & Weaknesses \\
\hline Liquidity & Native and toxic invading plants \\
Low risk & External mechanization dependence \\
Lower technological structure & Technological problems of the crop \\
Proceeds as income support & Resistance to change \\
Availability of labor & Age \\
Credit availability & Increase in animal concentration by area \\
Domain of production factors & Individualism \\
\hline Opportunities & Threats \\
\hline Savings reserve & Animal health \\
Lower impairment of equity & Debt \\
Lower indebtedness & Areas of marginal soils \\
Income diversification & Lack of scale \\
Profitability of labor & Succession \\
Opportunity for new investments & Low self-esteem \\
Decision-making ability. & \\
\hline
\end{tabular}

Stage 3 took place over two time points. In March 2014, the researchers defined the diagnostic criteria and indicators that were previously applied through a questionnaire. Along with the results obtained, the quality and efficiency of the indicators were evaluated, and were improved between April and September 2015. Together with the 32 indicators elaborated (Table 2), the questionnaires were adapted for the collection of field data.

Stage 4 - Measuring and monitoring the indicators selected in the Stage 3. From May to July 2016, a questionnaire was used to collect data from 90 family livestock production systems forming part of EMATER Santa Maria's business sector. The questionnaire included questions that allowed us to respond to the indicators established in Stage 3.

Stage 5 - Integration of results: reference values were established for each indicator using references in the literature or specific values for the case study under analysis. Optimum reference values varied according to the nature of the indicators. For each sustainability attribute, the indicators were weighted to reflect their relative importance in order to explain the sustainability of the system. This process often depends on a subjective score (MEUL et al., 2008). The researchers and extensionists participating in the meetings (Stages 1, 2, and 3) also ranked the indicators, within each sustainability attribute, in order of importance (the lowest weight was given to the least important indicator). The indicators used were diversified and expressed in both directions, both qualitative and quantitative. Then, the values for all indicators were transformed on a scale of 0 to 100 , corresponding to the worst ( 0 ) and the best (100) values. The values of the indicators and their weights were used to calculate the sustainability attributes of the studied production systems (\%). 
Table 2. Diagnostic criteria, indicators, description of the indicators and weighting within each MESMIS attribute, generated for the family livestock production systems in the Pampa biome.

\begin{tabular}{|c|c|c|c|c|}
\hline Attributes & Diagnostic criteria & Indicators & Description of Indicators & $\begin{array}{c}\text { Deliberation } \\
(\%)\end{array}$ \\
\hline \multirow{8}{*}{ 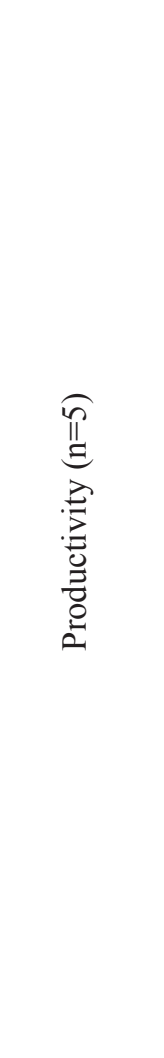 } & Economic viability & $\begin{array}{l}\text { Gross revenue from } \\
\text { other activities }\end{array}$ & $\begin{array}{l}\text { Observed values (\%). Lower percentage } \\
\text { corresponds to greater sustainability }\end{array}$ & 15 \\
\hline & Economic viability & Net revenue/UAA & $\begin{array}{l}\text { Observed values }(\%) \text {. Greater percentage } \\
\text { corresponds to greater sustainability }\end{array}$ & 25 \\
\hline & $\begin{array}{l}\text { Level of technifica- } \\
\text { tion }\end{array}$ & $\begin{array}{l}\text { Number of machines } \\
\text { and implements/ha } \\
\text { of crops }\end{array}$ & $\begin{array}{l}\text { Observed values }(\mathrm{cm}) \text {. Greater relation } \\
\text { corresponds to greater sustainability }\end{array}$ & 10 \\
\hline & $\begin{array}{l}\text { Relationship between } \\
\text { load and carrying } \\
\text { capacity of the native } \\
\text { field }\end{array}$ & Grass height & $\begin{array}{l}\text { Observed values }(\mathrm{cm}) \text {. Greater height } \\
\text { corresponds to greater sustainability }\end{array}$ & 20 \\
\hline & $\begin{array}{l}\text { Seasonal quality, age } \\
\text { of present species, } \\
\text { presence of small } \\
\text { invaders and/or dirty } \\
\text { field, uncovered soil. }\end{array}$ & $\begin{array}{l}\text { invasive forages and } \\
\text { soil cover }\end{array}$ & $\begin{array}{l}\text { Scale from } 1 \text { to } 6 \text {, where the most sus- } \\
\text { tainable value corresponds to } 1 \text { (covered } \\
\text { soil without invasives) }\end{array}$ & 20 \\
\hline & $\begin{array}{l}\text { Incorporation into } \\
\text { the system }\end{array}$ & $\begin{array}{l}\text { Culture incorpora- } \\
\text { tion time }\end{array}$ & $\begin{array}{l}\text { Level } 1 \text { (more sustainable): consolidated } \\
\text { crops. Level 2: unbound }\end{array}$ & 8 \\
\hline & $\begin{array}{l}\text { Percentual no Siste- } \\
\text { ma. }\end{array}$ & crops in the system & $\begin{array}{l}\text { Observed values }(\%) \text {. Lower } \% \text { of crops } \\
\text { corresponds to greater sustainability }\end{array}$ & 8 \\
\hline & Type of culture & $\begin{array}{l}\text { Presence of different } \\
\text { crops }\end{array}$ & $\begin{array}{l}\text { Level } 1 \text { (more sustainable): presence of } \\
\text { different crops, except soybean. Level } 2 \text { : } \\
\text { soybean cultivation }\end{array}$ & 4 \\
\hline \multirow{6}{*}{ 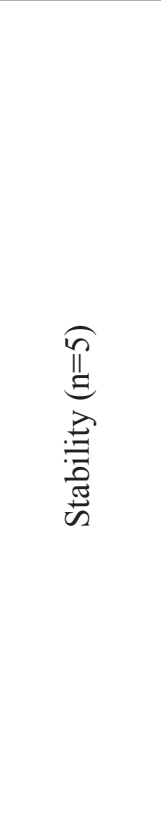 } & $\begin{array}{l}\text { Existence and predis- } \\
\text { position of succes- } \\
\text { sors to continue the } \\
\text { activity }\end{array}$ & $\begin{array}{l}\text { Existence and pre- } \\
\text { disposition to suc- } \\
\text { cession }\end{array}$ & $\begin{array}{l}\text { Scale from } 1 \text { to } 4 \text {, where the most sus- } \\
\text { tainable value corresponds to } 1 \text { (succes- } \\
\text { sor exists) }\end{array}$ & 20 \\
\hline & $\begin{array}{l}\text { Land in usufruct, } \\
\text { existence of other as- } \\
\text { sets, number of heirs }\end{array}$ & Hectares of land/heir & $\begin{array}{l}\text { Observed values, higher value of } \mathrm{H} / \mathrm{heir} \\
\text { being more sustainable }\end{array}$ & 20 \\
\hline & $\begin{array}{l}\text { House, light source, } \\
\text { water source, loco- } \\
\text { motion }\end{array}$ & $\begin{array}{l}\text { Housing and trans- } \\
\text { portation }\end{array}$ & $\begin{array}{l}\text { Scale from } 0 \text { to } 8 \text { (more sustainable), } \\
\text { considers the supply and quality of wa- } \\
\text { ter, light, housing, and transportation }\end{array}$ & 10 \\
\hline & $\begin{array}{l}\text { Health services and } \\
\text { working conditions }\end{array}$ & $\begin{array}{l}\text { Health and sanita- } \\
\text { tion }\end{array}$ & $\begin{array}{l}\text { Scale from } 0 \text { to } 5 \text { (more sustainable), } \\
\text { considers the supply and quality of } \\
\text { health services and working conditions }\end{array}$ & 10 \\
\hline & $\begin{array}{l}\text { Retirement/provi- } \\
\text { sion of services/other } \\
\text { income /animal pro- } \\
\text { duction }\end{array}$ & $\begin{array}{l}\text { Income origin of the } \\
\text { animal production }\end{array}$ & $\begin{array}{l}\text { Percentage of the total income with } \\
\text { origin of the observed animal produc- } \\
\text { tion, being more sustainable the greater } \\
\text { percentage }\end{array}$ & 20 \\
\hline & Legal reserve & $\begin{array}{l}\text { Area of native veg- } \\
\text { etation/total area }\end{array}$ & $\begin{array}{l}\text { Observed values }(\%) \text {. Greater percentage } \\
\text { corresponds to greater sustainability }\end{array}$ & 20 \\
\hline
\end{tabular}


continuation

\begin{tabular}{|c|c|c|c|c|}
\hline \multirow{4}{*}{ 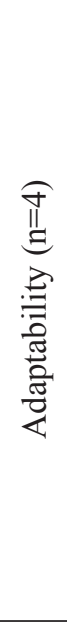 } & $\begin{array}{l}\text { Level of formal edu- } \\
\text { cation }\end{array}$ & Formal education & $\begin{array}{l}\text { Scale from } 0 \text { to } 5 \text {, where } 0 \text { represents } \\
\text { no formal education and level } 5 \text { (more } \\
\text { sustainable) represents higher education } \\
\text { in agriculture }\end{array}$ & 12.5 \\
\hline & $\begin{array}{l}\text { Productive and non- } \\
\text { productive capacity } \\
\text { in the last } 3 \text { years }\end{array}$ & $\begin{array}{l}\text { Number of training } \\
\text { courses in the last } 3 \\
\text { years }\end{array}$ & $\begin{array}{l}\text { Values observed, the more courses, the } \\
\text { more sustainable }\end{array}$ & 12.5 \\
\hline & $\begin{array}{l}\text { Level of participation } \\
\text { in collective spaces } \\
\text { in general }\end{array}$ & $\begin{array}{l}\text { Number of groups } \\
\text { in collective space } \\
\text { in general that par- } \\
\text { ticipate }\end{array}$ & $\begin{array}{l}\text { Observed values; greater participation, } \\
\text { more sustainable }\end{array}$ & 50 \\
\hline & $\begin{array}{l}\text { Participation in the } \\
\text { union (syndicate) }\end{array}$ & $\begin{array}{l}\text { Type of union par- } \\
\text { ticipation }\end{array}$ & $\begin{array}{l}\text { Scale from } 0 \text { to } 2 \text { (more sustainable), } \\
\text { where } 2 \text { effectively participate in trade } \\
\text { unions }\end{array}$ & 25 \\
\hline \multirow{10}{*}{ 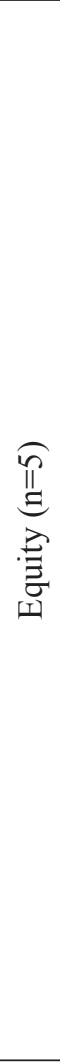 } & Animal welfare & $\begin{array}{l}\text { Quality of water, } \\
\text { shade and handling }\end{array}$ & $\begin{array}{l}\text { Scale from } 0 \text { to } 6 \text { (more sustainable), } \\
\text { consider supply and quality of water, } \\
\text { shade and management of animals }\end{array}$ & 5 \\
\hline & $\begin{array}{l}\text { Medicine for para- } \\
\text { sites }\end{array}$ & $\begin{array}{l}\text { Resistance to in- } \\
\text { ternal and external } \\
\text { parasites }\end{array}$ & $\begin{array}{l}\text { Scale from } 0 \text { to } 20 \text { (more sustainable), } \\
\text { considers the existence of resistance to } \\
\text { parasites in sheep and cattle }\end{array}$ & 6 \\
\hline & Improved native field & $\begin{array}{l}\text { Improved native } \\
\text { field in the system }\end{array}$ & $\begin{array}{l}\text { Observed values. Lower percentage indi- } \\
\text { cates greater sustainability }\end{array}$ & 7 \\
\hline & $\begin{array}{l}\text { Use of cultivated } \\
\text { pasture }\end{array}$ & $\begin{array}{l}\text { Pasture grown in the } \\
\text { system }\end{array}$ & $\begin{array}{l}\text { Observed values. The lower the percent- } \\
\text { age, the greater the sustainability }\end{array}$ & 7 \\
\hline & $\begin{array}{l}\text { Herd standardization } \\
\text { of the herd }\end{array}$ & $\begin{array}{l}\text { Herd standardization } \\
\text { scale }\end{array}$ & $\begin{array}{l}\text { Scale from } 0 \text { to } 7 \text { (more sustainable), } \\
\text { with } 0 \text { for non-standard and } 7 \text { for stan- } \\
\text { dard cattle and sheep }\end{array}$ & 5 \\
\hline & Recreation (leisure) & Leisure days/year & $\begin{array}{l}\text { Observed values. Greater recreation in- } \\
\text { dicates greater sustainability }\end{array}$ & 10 \\
\hline & $\begin{array}{l}\text { Diversification of } \\
\text { crops }\end{array}$ & $\begin{array}{l}\text { Number of different } \\
\text { crops }\end{array}$ & $\begin{array}{l}\text { Observed values. Greater number indi- } \\
\text { cates greater sustainability }\end{array}$ & 10 \\
\hline & $\begin{array}{l}\text { Conservation of } \\
\text { natural resources }\end{array}$ & $\begin{array}{l}\text { Number of soil con- } \\
\text { servation practices }\end{array}$ & $\begin{array}{l}\text { Observed values. Greater number indi- } \\
\text { cates greater sustainability }\end{array}$ & 10 \\
\hline & $\begin{array}{l}\text { Conservation of } \\
\text { natural resources }\end{array}$ & $\begin{array}{l}\text { Native field/total } \\
\text { area }\end{array}$ & $\begin{array}{l}\text { Observed values. Higher percentage } \\
\text { indicates greater sustainability }\end{array}$ & 20 \\
\hline & Use of agrochemicals & $\begin{array}{l}\text { Costs of agrochemi- } \\
\text { cals/UAA }\end{array}$ & $\begin{array}{l}\text { Observed values. Lower values refer to } \\
\text { greater sustainability }\end{array}$ & 20 \\
\hline \multirow{5}{*}{ 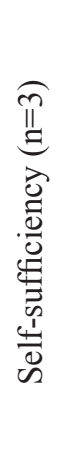 } & Land property & Total area as owner & $\begin{array}{l}\text { Observed values. The higher the percent- } \\
\text { age, the greater the sustainability }\end{array}$ & 20 \\
\hline & $\begin{array}{l}\text { Level of indebted- } \\
\text { ness }\end{array}$ & $\begin{array}{l}\text { Total annual debt/ } \\
\text { gross revenue }\end{array}$ & $\begin{array}{l}\text { Observed values. The lower the percent- } \\
\text { age, the greater the sustainability }\end{array}$ & 30 \\
\hline & Production system & $\begin{array}{l}\text { Diet in supplementa- } \\
\text { tion }\end{array}$ & $\begin{array}{l}\text { Observed values. The lower the percent- } \\
\text { age, the greater the sustainability }\end{array}$ & 10 \\
\hline & Self-consumption & $\begin{array}{l}\text { Number of self-con- } \\
\text { sumed products }\end{array}$ & $\begin{array}{l}\text { Observed values. Greater number indi- } \\
\text { cates greater sustainability }\end{array}$ & 20 \\
\hline & $\begin{array}{l}\text { Family work capac- } \\
\text { ity }\end{array}$ & $\begin{array}{l}\text { Family labor/total } \\
\text { workforce }\end{array}$ & $\begin{array}{l}\text { Observed values }(\%) \text {. Greater percentage } \\
\text { corresponds to greater sustainability }\end{array}$ & 20 \\
\hline
\end{tabular}

* The attribute-weighted total is $100 \%$. 
Stage 6 - Conclusions and recommendations: the evaluation is expressed in comparative terms among groups of family ranchers, performed through the typology of the production systems studied, based on the sustainability attributes of the MESMIS method. Agricultural systems typology is used widely in studies investigating the diversity of animal production systems (GARCIA-MARTINEZ et al., 2009). Multivariate analysis allows groups of production systems to be identified; with hierarchical grouping analysis of the five sustainability attributes, we classified the production systems of family farmers (cattle breeders from the same family) in the Pampa biome.

The grouping analysis allows a large group of subjects with maximum internal homogeneity to be classified, maximizing external heterogeneity (HAIR et al., 2006). The variables were previously standardized. The Euclidean squared distance and Ward method were used as a measure of distance and as a clustering algorithm, respectively (HAIR et al., 2006). Analysis of variance (ANOVA) was used to study the differences between sustainability groups. The analyzes were performed using SPSS (22.0).

\section{Result and Discussion}

\section{Characterization of production systems}

The 90 production systems studied are part of the EMATER-RS regional area of Santa Maria, located in the Pampa biome, with an average annual precipitation of $1776 \mathrm{~mm}$ distributed over 96 days per year, an average annual temperature of $20.1^{\circ} \mathrm{C}$, and negative temperatures in the winter and maximum temperatures that exceed $40^{\circ} \mathrm{C}$ in the summer.

Table 3 presents data on the production systems that characterizeit, prior to analysis of their sustainability. These results correspond to the initial stage of the study (definition and description of the systems) and provide us with an overview of the systems studied prior to the sustainability analysis.

Table 3. Average values for the general characteristics of family livestock production systems in the Pampa biome in 2016.

\begin{tabular}{lccc}
\hline & Mean & Minimum & Maximum \\
\hline Owner's age (years) & 53 & 22 & 79 \\
UAA $^{1}$ & $64 . .86$ & 5.00 & 224.00 \\
$\mathrm{AU}^{2}$ & 59.57 & 4.00 & 271.33 \\
AU/UAA & 0.92 & 0.80 & 1.21 \\
Number of calves/females of reproductive age & 0.45 & 0.00 & 5.00 \\
Ability to generate surplus & 8.80 & 0.00 & 60.75 \\
Costs/UAA & 883.62 & 30.81 & 4.716 .67 \\
Costs/AU & 916.46 & 86.10 & 4.707 .69 \\
UAA/HWU & 30.40 & 2.00 & 108.00 \\
AU/HWU & 28.92 & 1.76 & 135.67 \\
Net income/family HWU $^{\text {a }}$ & 23.800 .11 & 11.970 .00 & 181.660 .00 \\
\hline
\end{tabular}

${ }^{1}$ Usable agricultural area (UAA), in hectares; ${ }^{2}$ Animal unit (AU), equivalent to $450 \mathrm{~kg}$ of live weight; ${ }^{3}$ Human work unit (HWU); ${ }^{\mathrm{a}}$ Costs and revenues reported by the producer, not obtained through the traditional accounting method, expressed in Reais (R \$).

The average age of the rural property holder was 53 years, with the oldest producer being 79-years-old and the youngest 22-years-old. The Usable Agricultural Area (UAA) observed was 
64.86 hectares. The production systems presented 5-224 hectares UAA. On average, production systems had 59.57 Animal Unit (AU) at the time of data collection, with a minimum of $4 \mathrm{AU}$ and a maximum of $271.33 \mathrm{AU}$. Therefore, we observed a mean AU/UAA ratio of 0.92 AU per UAA hectare, with a minimum of 0.80 and a maximum of 1.21 AU/UAA.

To assess the reproductive performance of the herd, we used "number of calves/females of reproductive age". The number of calves per female of reproductive age observed was 0.45 , with a maximum of five and a minimum of zero.

Enjoyment could not be calculated based on the data collected. To approach this index, we calculated the "surplus capacity" of the system. The AU marketed was calculated based on the sales revenue of animals and the amount paid per kilogram of live animal. The number of AU marketed was divided by the number of animals existing at the time of data collection, generating the capacity to generate surpluses. The maximum value observed was 60.75 and the minimum 0 . The observed mean value was 8.80 .

Production costs are expressed through two indicators: costs per hectare of UAA and costs per AU. For the former, the average cost observed was
$\mathrm{R} \$ 883.62$ per hectare of useful agricultural land. There was a large difference between the minimum and maximum values observed, being $\mathrm{R} \$ 30.81$ and $4,716.67$, respectively. The average value per AU was $\mathrm{R} \$ 916.46$, with a minimum of $\mathrm{R} \$ 86.10$ and a maximum of $\mathrm{R} \$ 4,707.69$ observed.

Regarding labor, the UAA/HWU (Human Work Unit) and AU/HWU indicators showed that, on average, each individual worked 30.40 hectares of land and 28.92 livestock units. The minimum values for these indicators were 2 and 1.76, and the maximum values were 108.0 and 135.67 , respectively.

The indicator net revenue/family HWU demonstrates the labor remuneration presented by these systems. The average value observed was $\mathrm{R} \$ 23,800.11$ per man per year. The minimum amount, R\$ $-11,970.00$, indicating that instead of remunerating the workforce, some systems are generating debt. The maximum value observed was $\mathrm{R} \$ 181,660.00$.

\section{Typology of production system sustainability}

A cluster analysis based on the five MESMIS attributes identified three groups of production systems (Figure 2, Table 4).

Figure 2. Dendrogram with analysis of the grouping of the production systems of the family livestock in the Pampa biome in 2016 .

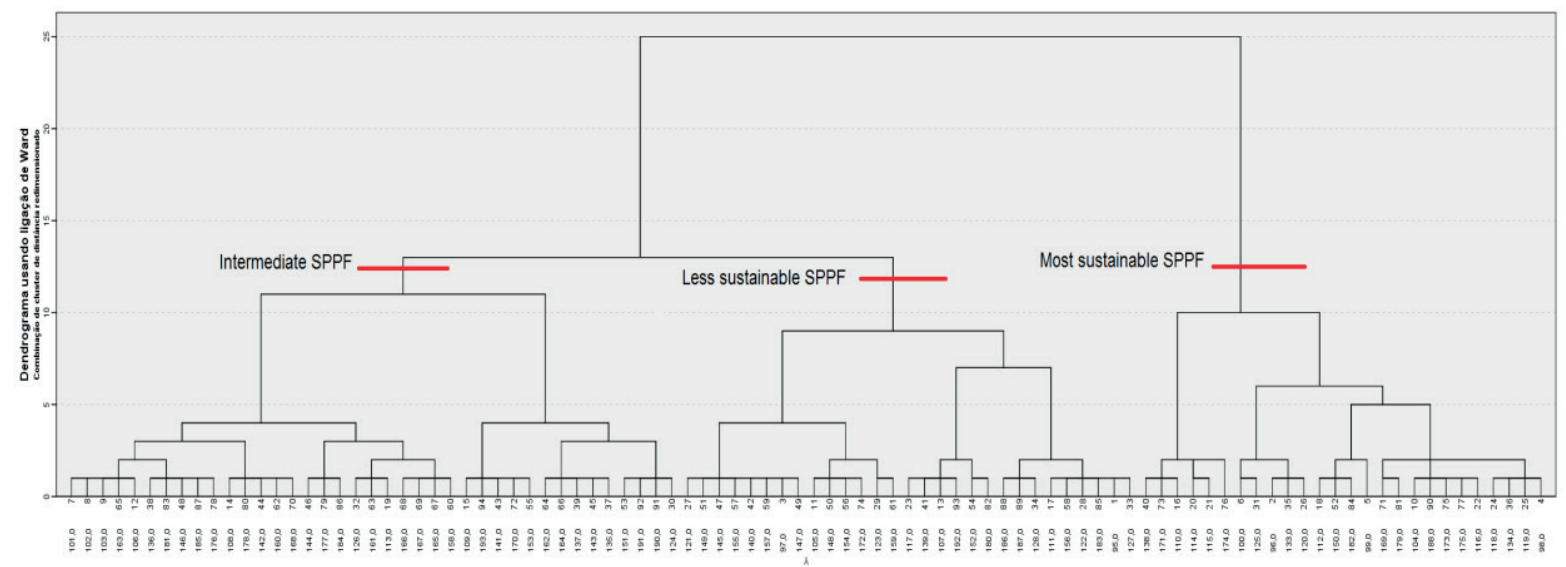

Semina: Ciências Agrárias, Londrina, v. 40, n. 6, suplemento 2, p. 3249-3268, 2019 
The least sustainable SPPF presented lower equity, were equal to the intermediate SPPF and productivity among the three groups $(\mathrm{p}<0.05)$. inferior to the more sustainable $\operatorname{SPPF}(\mathrm{p}<0.05)$. The values observed for stability, adaptability, and

Table 4. Mean scores obtained from groups for sustainability attributes of family livestock production systems in the Pampa biome in 2016.

\begin{tabular}{lccc}
\hline Group & $\begin{array}{c}\text { Most sustainable SPPF } \\
(\mathbf{n}=\mathbf{2 3})\end{array}$ & $\begin{array}{c}\text { Intermediate } \\
\text { SPPF }(\mathbf{n}=\mathbf{3 0})\end{array}$ & $\begin{array}{c}\text { Less sustainable SPPF } \\
(\mathbf{n}=\mathbf{3 7})\end{array}$ \\
\hline Productivity & $69.81^{\mathrm{a}}$ & $76.52^{\mathrm{a}}$ & $52.77^{\mathrm{b}}$ \\
Stability & $47.50^{\mathrm{a}}$ & $33.36^{\mathrm{b}}$ & $33.13^{\mathrm{b}}$ \\
Adaptability & $18.03^{\mathrm{a}}$ & $7.30^{\mathrm{b}}$ & $11.61^{\mathrm{b}}$ \\
Equity & $84.08^{\mathrm{a}}$ & $68.77^{\mathrm{b}}$ & $69.23^{\mathrm{b}}$ \\
Self-sufficiency & $35.86^{\mathrm{a}}$ & $39.18^{\mathrm{a}}$ & $33.83^{\mathrm{a}}$ \\
\hline
\end{tabular}

ANOVA. Same attributes with different letters indicate significant differences between groups. $(p<0.05)$.

The most sustainable SPPF had the greatest stability, adaptability, and equity $(\mathrm{p}<0.05)$. Productivity was higher than the least sustainable SPPF and equal to that of the intermediate SPPF ( $p$ $<0.05)$.

Conversely, the intermediate SPPF presented higher productivity than the least sustainable SPPF $(\mathrm{p}<0.05)$, with no statistical difference to the most sustainable SPPF. Stability, adaptability, and equity values did not differ from the least sustainable SPPF and were lower than the most sustainable SPPF (p $<0.05$ ). Values for self-sufficiency did not differ between groups.

Figure 3 provides an integrated view of the results for sustainability attributes.

Figure 3. Mean scores obtained for sustainability attributes in the family livestock production systems in the Pampa biome in 2016.

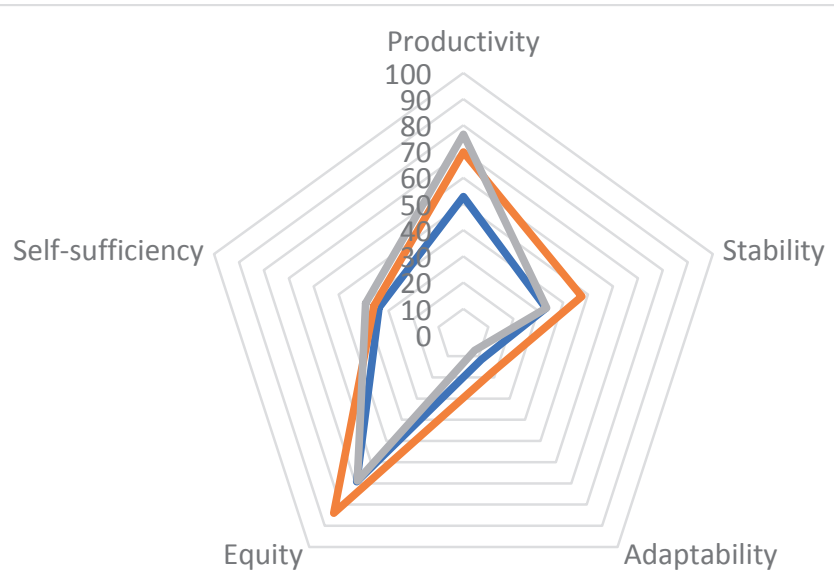


Intermediate SPPF demonstrated high productivity, surpassing the least sustainable SPPF for productivity, and being equal to the most sustainable SPPF. For the remaining attributes, it was equal to the least sustainable SPPF for stability, adaptability, and equity.
To better describe and characterize the groups, we analyzed the indicators comprising each sustainability attribute. Figure 4 shows the results obtained for productivity indicators.

Figure 4. Mean scores obtained among groups for indicators of the attribute productivity in family livestock production systems in the Pampa biome in 2016.

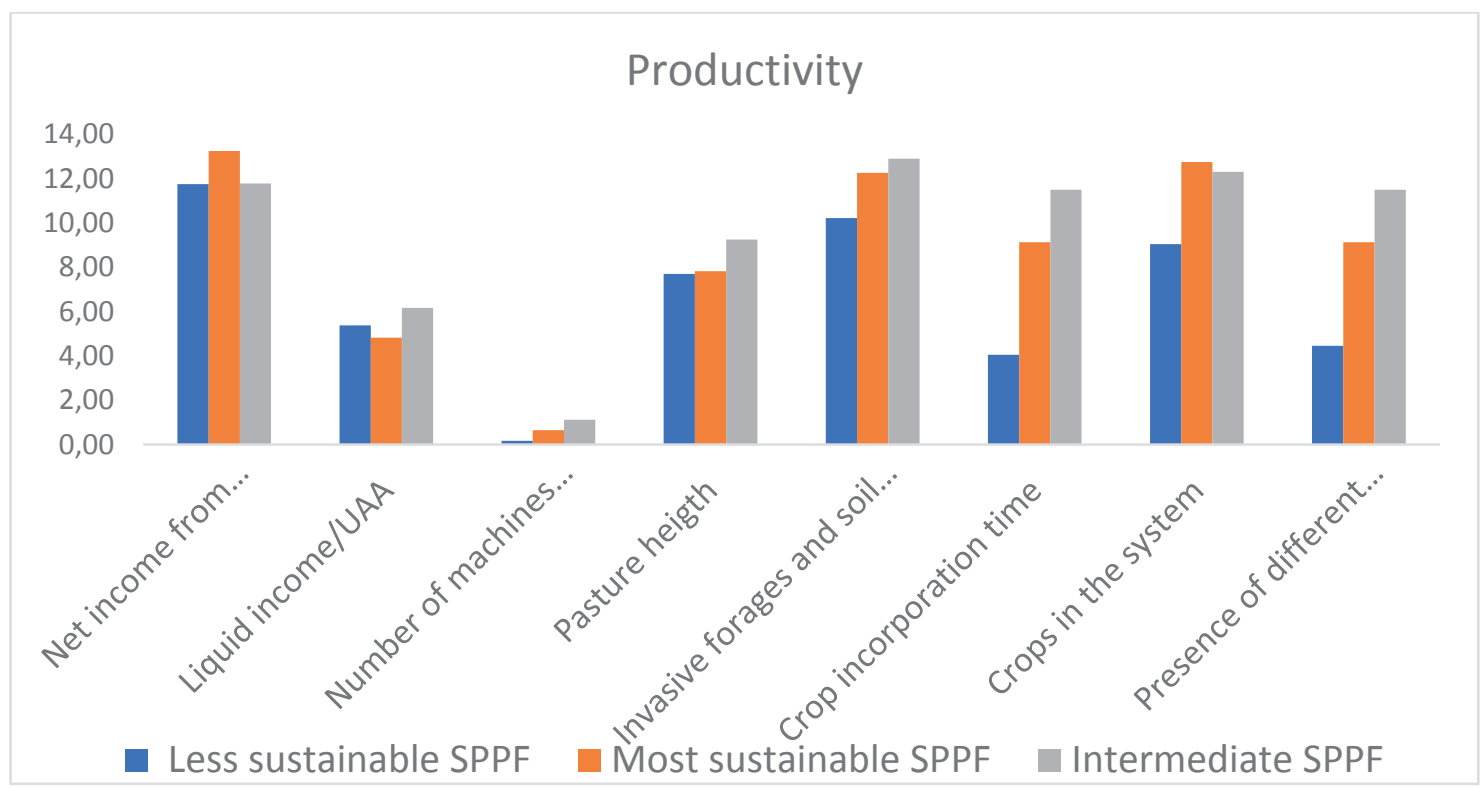

The group with the worst result for sustainability was the least sustainable SPPF, which presented lower productivity. The score of this group for the indicator "crops in the system" was the lowest among the three groups, as well as for the indicators "presence of different crops", "crop incorporation time", "invasive forages and soil cover", and "pasture height ". Thus, in this group, the production systems presented a higher crop percentage and more recent incorporation into the system, with a higher presence of soybean cultivation among the three groups.

The highest percentage of crops in the system and the most recent incorporation seems to reflect the results for "invasive forages and soil cover" and "pasture height". The lowest score for these indicators demonstrates the presence of greater proportions of uncovered soil and invasive species, as well as lower grass height, in this group.

Although the least sustainable SPPF presented a higher percentage of crops, especially soybeans, in systems, it presented "liquid income/ha of UAA" that was lower than that of the intermediate SPPF. Regarding the participation of other revenues ("net income from another activity"), the results for the least sustainable SPPF were the same as those for the intermediate SPPF and inferior to those of the most sustainable SPPF; thus, there is a high influx of activities originating outside the system of livestock production in this group.

The most sustainableSPPF, with statistically equal productivity to the intermediate SPPF, presented the best result for the indicator "crops in the system"; thus, it has a smaller crop area compared with the 
other groups. However, in this group, the "presence of different crops" indicates a greater presence of the soybean crop than the intermediate SPPF and a lower presence than in least sustenable SPPF. The indicators "crop incorporation time", "invasive forages and soil cover", and "pasture height" also follow the pattern observed in the least sustainable SPPF. The most sustainable SPPF obtained lower "net Revenue/UAA" and a lower share of revenues from outside the production system.

The intermediate SPPF, which has high productivity, performed worse for "crops in the systems" than the most sustainable SPPF, because it presents a greater area of cultivation. However, this larger area of cultivation includes less of soybean cultivation and these areas of cultivation are already established, with a longer incorporation time in the system. The other indicators, except for "net income from another activity", were higher than in the other groups.

The results for the stability indicators are shown in Figure 5.

Figure 5. Mean scores obtained among groups for indicators of the attribute stability of family livestock production systems in the Pampa biome in 2016.

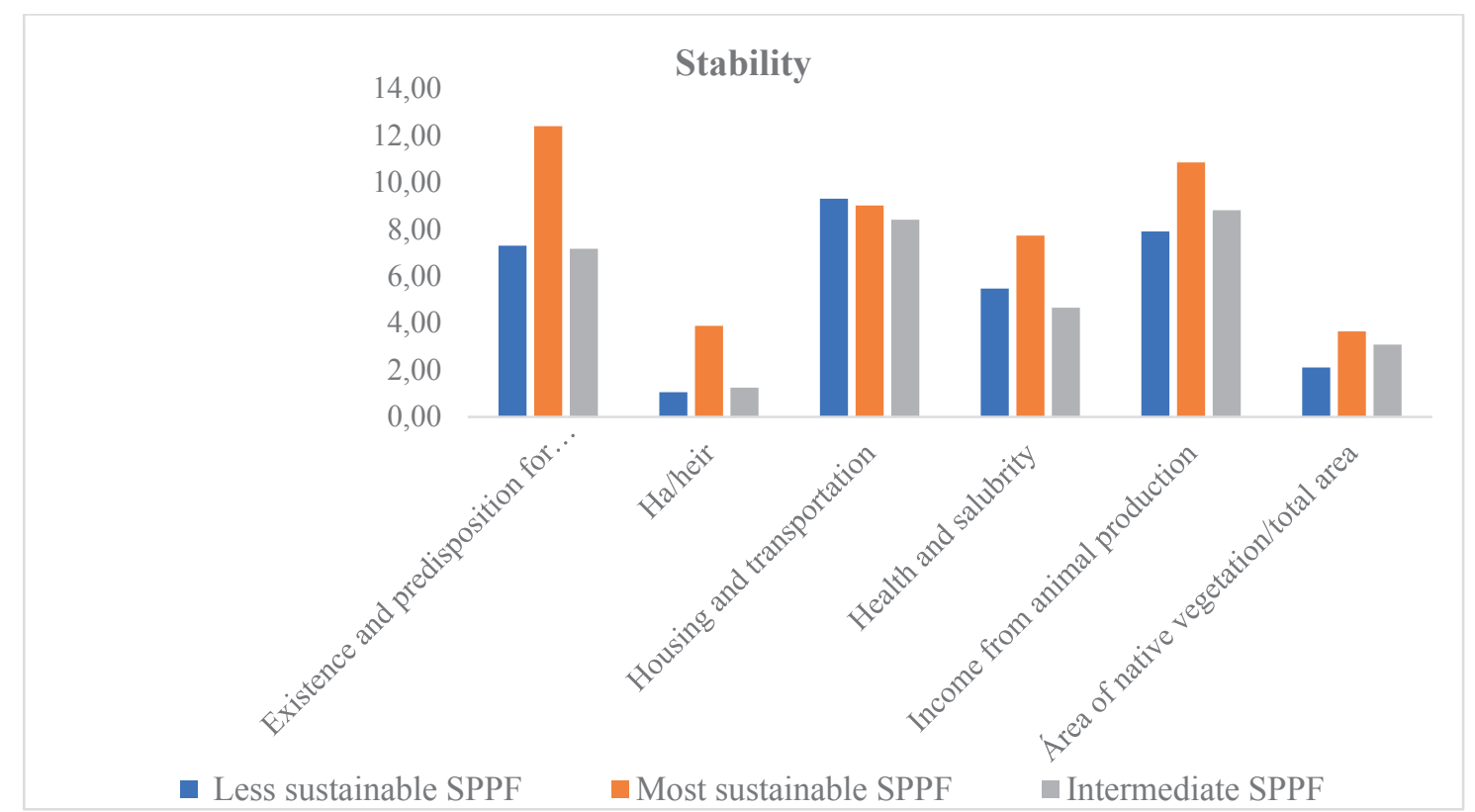

There were no significant differences in the indicators composing the stability attribute between the least sustainable SPPF and the intermediate SPPF; these groups were inferior to the most sustainable SPPF, except for "housing and transport" for which the least sustainable SPPF showed the best result.

The most sustainable SPPF presented the greatest possibility for succession, due to the existence of heirs and the number of hectares of land per heir, which enables the continuation of the activity by the successor. The best result for the indicator "income from animal production" shows that the most sustainable SPPF is based more on cattle activity than the other groups. The most sustainable SPPF also presented a higher percentage of native vegetation/total area, which, in terms of the presence of legal reserve, contributes to the stability of the production systems. 
Figure 6 shows that indicators of the adaptability attribute. In general, it is necessary to emphasize the low performance of the three groups in relation to this attribute. The scores of the least sustainable SPPF and the intermediate SPPF groups were 11.01 and $7.3 \%$, respectively. Adaptability refers to the ability of an agroecosystem to regain stability following adverse situations.
The most sustainable SPPF group outperformed all other groups (which did not differ between themselves) in all indicators. In this group, a higher level of formal education was provided to the holder of the rural property; thus, there was a higher level of schooling within this group. Despite the low score achieved, the most sustainable SPPF also presented the highest value for "number of training courses in the last 3 years".

Figure 6. Mean scores obtained among groups for indicators of the attribute adaptability for family livestock production systems in the Pampa biome in 2016.

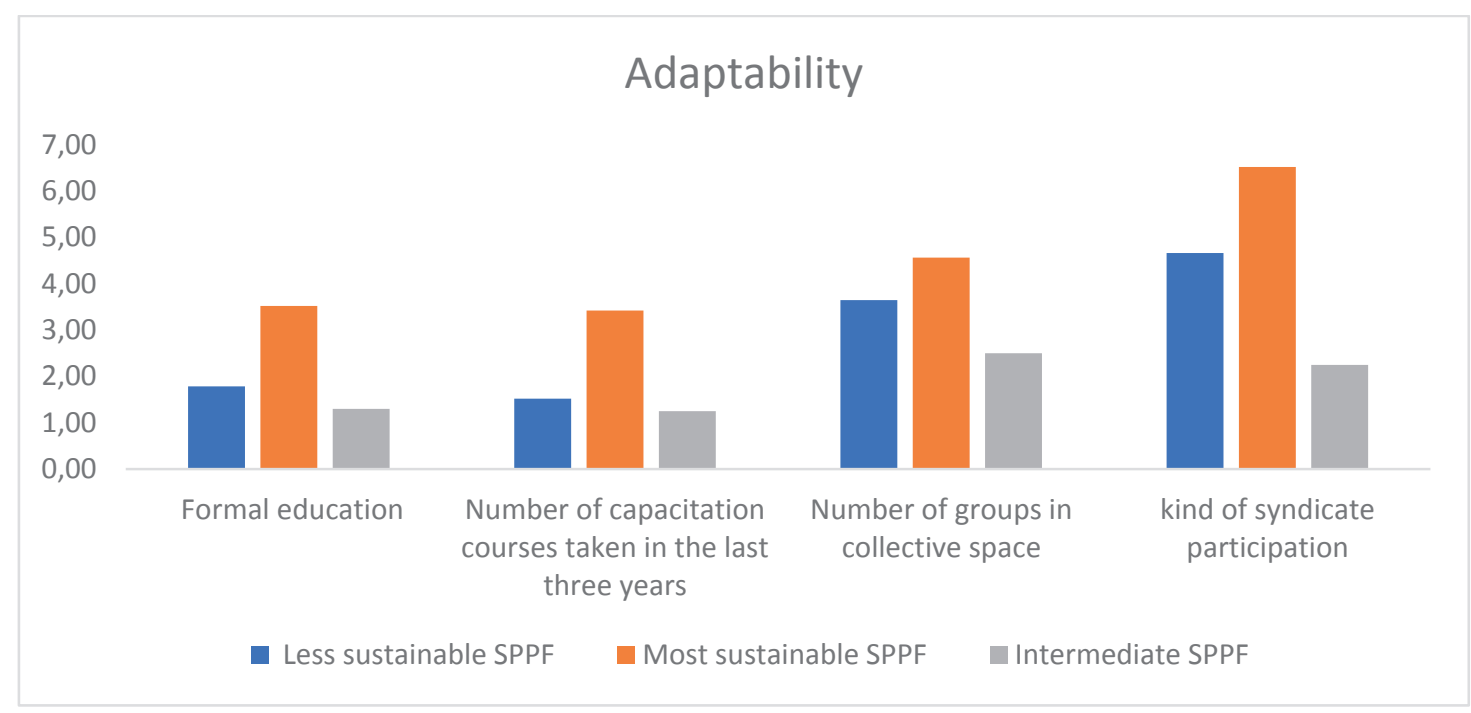

Indicators of the equity attribute (Figure 7) aim to demonstrate the benefits of using natural resources, considering the costs of each management practice. 
Figure 7. Mean scores obtained among groups for indicators of the equity of livestock production systems in the Pampa biome in 2016.

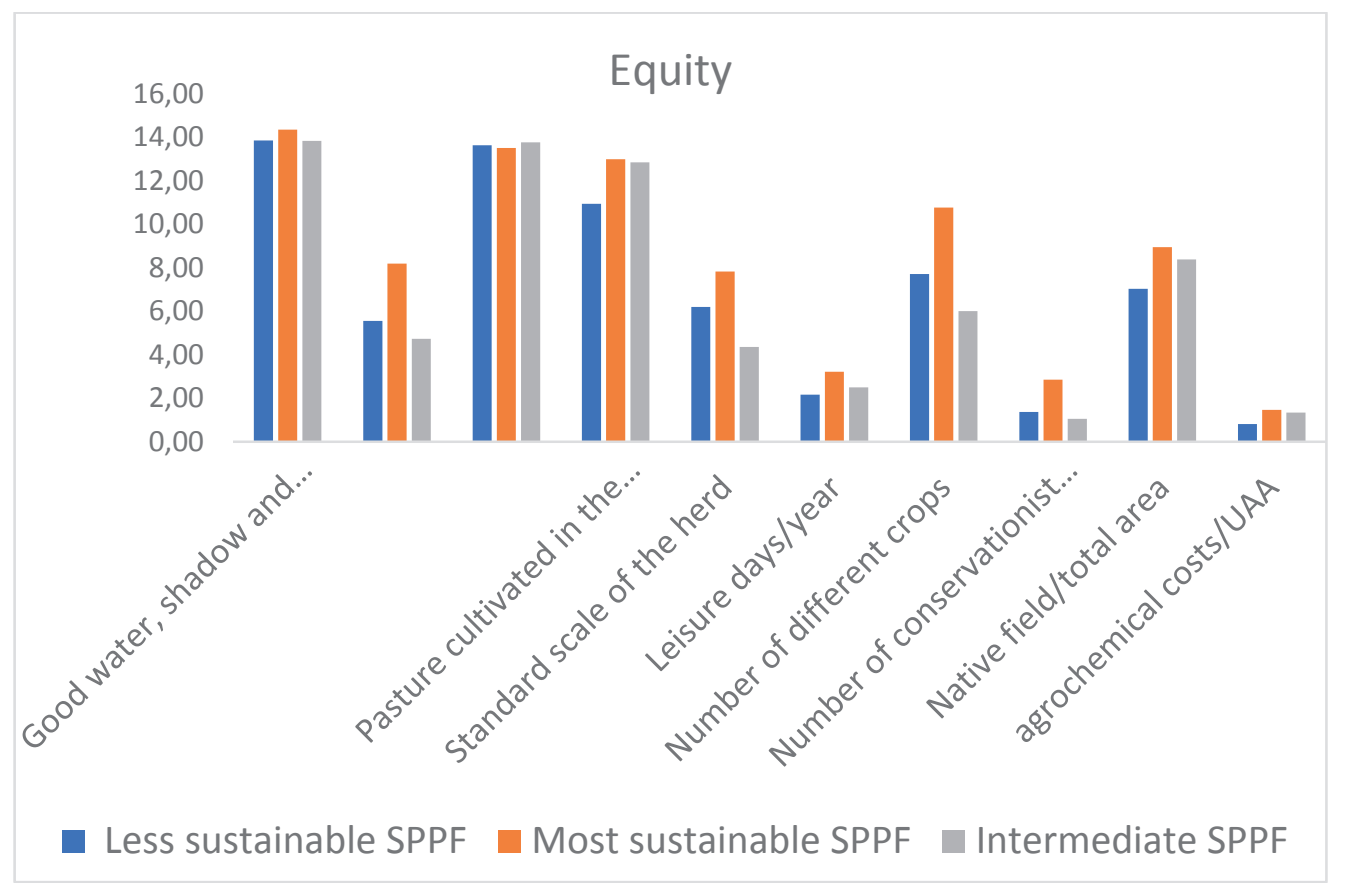

For equity, the largest differences between groups were observed for the indicators "herd standardization scale", "number of different crops", "leisure days/year", "number of conservation practices", "total", "costs of agrochemicals/UAA", and "resistance to internal and external parasites"; the most sustainable SPPF group was superior to the other groups for all indicators. The indicator "native field improved in the system" was similar between all three groups.

Unlike the most sustainable SPPF, the least sustainable SPPF is the one that presents the lowest native field/total area ratio.

Due to the higher percentage of crops (in the productivity attribute), the least sustainable SPPF presented higher cost of agrochemicals per hectare of UAA and more pastures cultivated in the system, resulting in a lower score for these indicators. The number of soil conservation practices presented a higher score for the most sustainable SPPF, followed by the least sustainable SPPF and later the intermediate SPPF, as well as the indicator "resistance to external and internal parasites. Little difference in the other indicators was observed between groups.

Figure 8 presents the indicators that are part of the self-sufficiency attribute. The indicators show that, in relation to land ownership, the most sustainable SPPF is the group with the lowest percentage of own land, with the intermediate SPPF having the best result for this indicator. The indicator "total surface as owner" demonstrates the relationship between owning land and using land under the leasing system, in which the system operates. 
Figure 8. Mean scores obtained among groups for indicators of the equity of the livestock production systems in the Pampa biome in 2016.

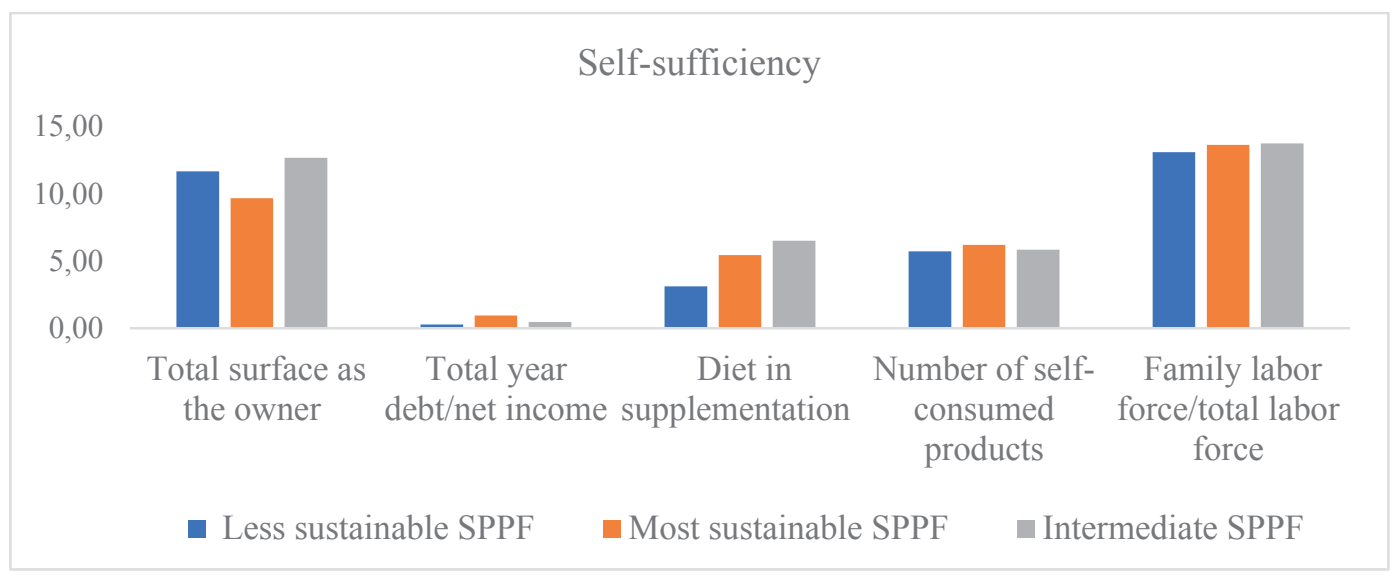

Regarding the level of indebtedness, the best result was obtained for the most sustainable SPPF and the highest level of indebtedness was observed for the least sustainable SPPF. The level of indebtedness of the production system is represented by the indicator "total annual debt/net income"; therefore, this relates the annual debts to the gross income. The least sustainable SPPF presented the worst score for "percentage ration in supplementation"; thus, this group uses more supplementation than the other groups. Regarding the number of self-consumed products and "family labor force/total labor force", the values for the most sustainable SPPF were slightly higher than those for the other groups. With this association between indicators, no significant difference was observed for the self-sufficiency attribute between the groups.

Diagnostic criteria of the indicator "pasture height" include the relationship between capacity and animal load in the native field. In this study, the use of forage and grassland structure was also affected by grass height (PONTES et al., 2003; CAUDURO et al., 2007). Greater grazing pressure and consequent lower pasture height contribute to the occurrence of exposed soils and a greater presence of invasive species The conversion and incorporation of new areas of agricultural crops, mainly soybean, causes a mismatch in the animal load, which were previously supported by the system, increasing the grazing pressure on the native field area, resulting in lower pasture height and greater presence of invasive species.

Notably, the "number of machines and implements" does not clearly express the degree of technification that was intended to be demonstrated. This indicator does not consider the capacity of machines and implements; thus a production system with large UAA can be serviced with a high capacity machine while a production system with lower UAA may not have its requirements covered with more than one low capacity machine.

Analyzed together with the productivity indicator, participation of agriculture is lower in this group (better result for "crops in the system"), as well as a greater dependence on external income for agricultural activity, and lower "liquid income / UAA". Severo and Miguel (2006) observed that "in general, exclusively beef cattle production systems presented very low or even negative agroeconomic and efficiency results, with a high dependence on non-agricultural incomes". ....

Ribeiro (2009) found that $75 \%$ of family ranchers and their families had never participated in any type of formal education. This finding coincides with the low sustainability percentage for the adaptability attribute according to the indicators that compose it. 
In this study, the adaptability of the systems was linked directly to the formal training and participation of family ranchers. It is understood that a higher level of formal education, training for activity and participation in different environments related to the activity sector, prepare the family farmer for decision-making in the face of challenges and crises that may arise. This expands the possibility of identifying suitable solutions for each situation, resulting in the system being adaptable to new conditions. The absence of formal education does not annul personal capacity; however, according to Ribeiro (2009), it may hinder full potential.

The low participation of cattle ranchers in collective spaces and unions demonstrates the individualistic characteristic of the rural producer, as highlighted in several studies (RIBEIRO, 2009; PORTO et.al., 2010; NORONHA; HESPANHOL, 2006; FERREIRA et al., 2009).

The management and conservation of native fields were strongly emphasized, demonstrated directly or indirectly through several indicators. The most sustainable SPPF presented a higher percentage of native field over the total area of the production system. This indicator favors a greater presence of native field in the production systems due to the specificity of its presence for the Pampa biome. "It is a fantastic genetic heritage and rarely found in other pastoral biomes on the planet. But more than a genetic heritage, this diversity is important because it characterizes a diversified diet, which confers particular characteristics to the animal product obtained there "(NABINGER, 2006).

The attribute self-sufficiency, following adaptability, presented the worst result among the sustainability attributes proposed by MESMIS. Although family livestock production systems are less dependent on external inputs because of their intrinsic characteristics, according to the proposed analysis, they do not guarantee a higher level of self-sufficiency.

Although the systems studied were based on animal production, which occurred more extensively than in other production systems, and were thus more dependent on natural resources, there are critical points for these systems that are demonstrated by the indicators.

Land ownership is important; leased land represents uncertainty in the future of the system.

High levels of indebtedness, even if the debt is made for investment purposes, are worrisome, since they compromise the future of the activity by increasing the risks of the activity.

The least sustainable SPPF group includes the largest areas of soybean cultivation in the system, which is related to higher indebtedness due to the need for investments and the use for external inputs to be greater than in systems that present a greater participation of animal production than soy cultivation.

Although this group presents larger areas of crops in the system, when analyzed with the indicator of pastures grown in the system, this result shows that the soybean-growing areas in the summer are not used by the system in the winter with pastures cultivated for animal production, which makes it necessary to seek alternative nutritional management, such as supplementation.

In the context of the uncertainties in which they are inserted, attributes such as stability, adaptability, and self-sufficiency are pf relevance for production systems that present good levels of productivity (RIPOLL et al., 2012). Although the complexity inherent when studying the evolution of agricultural production systems and the advent of soybean cultivation in the Pampa biome, the MESMIS method associated with multivariate analysis (hierarchical grouping) was efficient for the typology of the production system of family cattle breeding.

Thus, due to the specificities of the environment and dynamics to which they are exposed, the sustainability of the production systems studied is 
in the balance between agriculture and livestock, systems and management practices. Soybean expansion in the SPPF reflects the need for alternatives to increase income, which is a key point of these systems. Ripol et al. (2013) studied the sustainability of Mediterranean systems of sheep production with different levels of intensification, and emphasized the importance of income and the remuneration of labor as a way to guarantee the permanence of producers in this activity. To some extent, agriculture makes the existence of livestock possible. However, the excessive expansion of one activity over anther in the Pampa biome results in a decrease in sustainability, both on environmental, social, and economic levels.

"Despite current concerns about the global environmental impacts of livestock production, local stakeholders prioritize economic, social development, and few local environmental sustainability factors" (RIPOLL et al., 2012). Diversification is a relevant strategy; however, diversification of production and resource use, or sources of income, are limited in sheep and cattle breeding systems (BERNUÉS et al., 2011). Appropriate management alternatives to the Pampa biome may allow the profitability of livestock to compete with that of soybean cultivation, particularly when associated with public policies for the conservation of this biome, avoiding the continuing degradation and suppression of native fields, with the loss of biodiversity that this entails.

\section{Conclusions}

Application of the MESMIS method associated with typology through a cluster analysis allowed the identification of three types of family livestock production systems \#in the central region of RS state in the Pampa biome.

The least sustainable SPPF has the most relevant characteristics: larger areas of cultivation in the production systems that integrate it, among these crops, a greater presence of soybean cultivation, lower income from animal production, smaller legal reserve area, and a smaller field area in the systems. In addition, they present higher costs with fertilizers and pesticides. Rural property owners enjoy fewer leisure days per year compared with those in other groups.

The most sustainable SPPF presented smaller crop areas in production systems, less soybean participation among crops (although it is present), higher income from animal production, greater native field area, more standardized herd, a higher level of formal education and participation of producers, and more crops, resulting in more diversified systems.

The intermediate SPPF, with intermediate results in relation to the other two groups regarding sustainability, presented statistically equal productivity to the most sustainable SPPF and superior to the least sustainable SPPF $(p<0.05)$. Although this group presented smaller areas of cultivation than the most sustainable SPPF, presence of soybean cultivation was higher in this group, and there was a higher net revenue per hectare of UAA. For the other attributes, the intermediate SPPF did not differ from the least sustainable SPPF, even for the attribute self-sufficiency, where all groups were equal.

\section{References}

BARBIER, J. M.; LÓPEZ-RIDAURA, S. Evaluation de la durabilité des systèmes de production agricoles: limites des démarches normatives et voies d'amélioration. In: ISDA INTERNATIONAL SYMPOSIUN, 2010, Montpellier. Anais... Montpellier, 2010. p. 3-9.

BELZLEPKINA, I. REIDSMA, P.; SIEBER, S.; HELMING, K. Integrated assessment of sustainability of agricultural systems and land use: methods, tools and applications. Agricultural Systems, Amsterdam, v. 104, n. 2, p. 105-109, 2011. DOI: 10.1016/j.agsy.2010.11.002 BERNUÉS, A.; RUIZ, R.; OLAIZOLA, A.; CASASUS, I. Sustainability of pasture-based livestock farming systems in the European Mediterranean context: synergies and trade-offs. Livestock Science, Amsterdam, v. 139, n. 1-2, p. 44-57, 2011. DOI: 10.1016/j.livsci.2011.03.018 
BINDER, C.R.; FEOLA, G.; STEINBERGER, J. K. Considering the normative, systemic and procedural dimensions in indicator-based sustainability assessments in agriculture. Environmental Impact Assessment Review, Amsterdam, v. 30, n. 2, p. 71-81, 2010. DOI: 10.1016/j. eiar.2009.06.002

BRASIL. Pampa: conhecimentos e descobertas. Brasília: Ministério do Meio Ambiente, 2014. n.1, p 1-3. Disponível em: http://www.mma.gov.br/biomas/pampa/. Acesso em: 25 mar. 2017.

CAUDURO, G. F. Fluxo de biomassa aérea em azevém anual manejado sob duas intensidades e dois métodos de pastejo. Revista Brasileira de Zootecnia, Viçosa, MG, v. 36, n. 2, p. 282-290, 2007. DOI: 10.1590/S151635982007000200003

CHOMENKO, L. Implantação de monoculturas: o desenvolvimento na metade sul do Rio Grande do Sul, Brasil. Porto Alegre: Ecoagencia, 2006. n. 1, 1p. Disponível em: http://www.ecoagencia.com.br/?open= listartigos. Acesso em: 15 maio 2017.

FERREIRA, P. A, ALENCAR, E.; PEREIRA, J. R.; SANTANA, A. C. Estado e agricultores familiares: uma análise interpretativa sobre o desenvolvimento rural no Sul de Minas Gerais. Revista de Economia e Sociologia Rural, Rio de Janeiro, v. 47, n. 3, p. 769-792, 2009. DOI: 10.1590/S0103-20032009000300011

GARCIA-MARTINEZ, A.; OLAIZOLA， A. M.; BERNUES, A. Trajectories of evolution and drivers of change in European mountain cattle farming systems. Animal, Cambidge, v. 3, n. 1, p. $152-165$, 2009. DOI: $10.1017 / \mathrm{S} 1751731108003297$

GIBON,A.;SIBBAD,A.R.;FLAMANT,J.C.; REVILLA, R.; RUBINO, R.; SORENSEN, J. T. Livestock farming systems research in Europe and its potential contribution for managing towards sustainability in livestock farming. Livestock Production Science, Amsterdam, v. 61, n. 2-3, p. 121-137, 1999. DOI: 10.1016/S0301-6226(99)000627

HAIR, J. F.; BLACK, W. C.; BABIN, B. J.; ANDERSON, R. E. Multivariate data analysis. $6^{\text {th }}$ ed. Upper Saddle River: Pearson Prentice Hall, 2006. 739 p.

LÓPEZ-RIDAURA， S.; MASERA, O.; ASTIER, M. Evaluating the sustainability of complex socioenvironmental systems: the MESMIS framework. Ecological Indicators, Amnstedam, v. 2, n. 1-2, p. 135148, 2002. DOI: 10.1016/S1470-160X(02)00043-2

MEUL, M.; PASSEL, S.V.; NEVENS, F.; DESSEIN, J. A monitoring tool for integrated farm sustainability. Agronomy for Sustainable Development, Paris, v. 28, n. 1, p. 321-332, 2008. DOI: 10.1051/agro:2008001
NABINGER, C. Manejo e produtividade das pastagens nativas do subtrópico brasileiro. In: SIMPÓSIO DE FORRAGEIRA E PRODUÇÃO ANIMAL, 1., 2006, Porto Alegre. Anais... Porto Alegre: UFRGS, 2006. p. 25-76.

NORONHA, E. O.; HESPANHOL, R. A. M. Perspectiva da produção agrícola familiar em relação ao associativismo rural: um estudo de caso no Município de Presidente Prudente (SP). In: ENCONTRO DE GUPOS DE PESQUISA DO INSTITUTO DE GEOGRAFIA, UFU, 2., 2006, Uberaba. Anais... Uberaba: UFU, 2006. p. $32-40$.

PIZZATO, F. Pampa gaúcho: causas e consequências do expressivo aumento das áreas de soja. 2013. Dissertação (Mestrado em Geografia) - Universidade Federal do Rio Grande do Sul, Porto Alegre.

PONTES, L. S.; CARVALHO, P. C. F.; NABINGER, C.; SOARES, A. B. Fluxo de biomassa em pastagem de azevém anual (Lolium multiflorum Lam.) manejada em diferentes alturas. Revista Brasileira de Zootecnia, Viçosa, MG, v. 32, n. 4, p. 814-820, 2003. DOI: 10.1590/ S1516-35982004000300002

PORTO, R. G.; BEZERRA, A. J. A.; PORTO, V. H. F.; CALDAS, N. V. Pecuária familiar: a emergência de uma categoria social no Sul do Brasil. Revista Economia e Sociologia Rural, Rio de Janeiro, v. 48, n. 2, 2010. DOI: 10.1590/S0103-20032010000200010

RIBEIRO, C. M. Estudo do modo de vida dos pecuaristas familiares da Região da Campanha do Rio Grande do Sul. 2009. Tese (Doutorado em Desenvolvimento Rural) - Universidade Federal do Rio Grande do Sul, Porto Alegre.

RIO GRANDE DO SUL. Decreto $\mathrm{n}^{\circ}$ 48. 316, de 31 de agosto de 2011. Diário Oficial [do] Estado do Rio Grande do Sul, Porto Alegre, n. 170, 1 set. 2011. 4 p.

RIPOLL B., R.; DÍEZ-UNQUERA, B.; RUIZ, R.; VILLALBA, D.; MOLINA, E.; JOY, M.; OLAIZOLA,A.; BERNUÉS, A. An integrated sustainability assessment of mediterranean sheep farms with differente of intensification. Agricultural Systems, Amsterdam, v. 105, n. 1, p. 46-56, 2012. DOI: 10.1016/j.agsy.2011.10.003

RIPOLL B., R.; JOY, M.; BERNUÉS, A. Role of self-sufficiency, productivity and diversification on the economic sustainability of farming systems with autochthonous sheep breeds in less favoured areas in Southern Europe. Animal, Amsterdam, v. 7, n. 8, p. 1-9, 2013. DOI: $10.1017 / \mathrm{S} 1751731113000529$

RODRIGUES, A. de L. O latifúndio no Rio Grande do Sul, velhas formas na funcionalidade de novos atores econômicos na Microrregião Geográfica da Campanha 
Central. 2006. Dissertação (Mestrado em Geografia) Universidade Federal de Santa Maria, Santa Maria.

SEVERO, C. M.; MIGUEL, L. A. A sustentabilidade dos sistemas de produção de bovinocultura de corte do estado do Rio Grande do Sul. REDES-Revista de Desenvolvimento Regional, Santa Cruz do Sul, v. 11, n. 3, p. 213-234, 2006.

SILVEIRA, V. C. P.; GONZÁleZ, J. A.; FONSECA, E. L. Land use changes after the period commodities rising price in the Rio Grande do Sul State, Brazil. Ciência Rural, Santa Maria, v. 47, n. 4, 2017. DOI: 10.1590/0103$8478 \mathrm{cr} 20160647$
SPEELMAN, E. N.; LOPEZ-RIDAURA, S.; COLOMER, N. A.; ASTIER, M.; MESERA, O. R. Ten years of sustainability evaluation using the MESMIS framework: Lessons learned from its application in 28 Latin American case studies. International Journal of Sustainable Development and World Ecology, Londres, v. 14, n. 4, p. 345-361, 2007. DOI: 10.1080/13504500709469735

WAQUILL, P. D.; MATTE, A.; NESKE, M. Z. Pecuária familiar no Rio Grande do Sul: a ressignificação de uma categoria social. In: WAQUILL, P. D.; MATTE, A.; NESKE, M. Z.; BORBA, M. F. S. (Org.). Pecuária familiar no Rio Grande do Sul: história, diversidade social e dinâmica de desenvolvimento. Porto Alegre: Editora da UFRGS, 2016. p. 11-14. 
